\title{
Regional Study on Behavioural Tendency in Adolescents: Assessment and Analysis of Personal and Socio-Economic Environment
}

\author{
Deepika Sharma* and Sheela Sangwan \\ Department of Human development \& Family Studies, I.C College of Home Science, \\ CCSHAU, Hisar \\ *Corresponding author:
}

\begin{abstract}
A B S T R A C T
The present study "Regional Study on Behavioural Tendency in Adolescents: Assessment

Keywords

Adolescents, Aggressiveness, Impulsivity, Vigorous

Article Info

Accepted:

18 July 2019

Available Online:

10 August 2019

and Analysis of Personal and Socio-Economic Environment" was undertaken with the specific objectives viz (i) to analyse the personal and socio-economic profile of adolescents, (ii) to identify the factors influencing adolescents' aggression. The data was collected from Hisar District of Haryana. A total sample of 250 adolescents' in the age group of 13-15 years was randomly selected. Aggression scale developed by Mathur and Bhatnagar (2012) was used to study the aggressive behaviour. The collected data were tabulated, processed and analyzed by employing statistical technique i.e. frequencies, $\mathrm{z}$ test and regression analysis. The results of study indicated that in rural area; physical aggression was significantly more in male adolescents while verbal and relational aggression was significantly high in female adolescents. Similarly in urban area, male adolescents had significantly high physical and verbal aggression whilst relational aggression was high in female adolescents. Gender, family income, ordinal position, paternal education and maternal education came out as a significant predictors of the aggression in adolescents.
\end{abstract}

\section{Introduction}

Adolescence is termed as the transition period between childhood and adulthood. Human beings all through their life time learn and evolve themselves to deal better with their emotions. At every stage of their life they come across various kinds of emotions as there is a constant change in their role and responsibilities. At adolescence age a person start interacting with the world and go through various stress, anxiety, unsuriety while dealing with factors which are new to them. There is significant change in his thinking and thought process. There is major stress level that a adolescents face and much goes through in his mind and life in these ever changing times. There is a constant threat that a growing adolescent may resort to some unwanted means to overcome such anxiety levels. It may also bring out suicidal tendencies within them. Adolescents' aggressive behavior is the most commonly observed and is end result of this change. This behavior is among the most prevalent and challenging problem for society. Immense 
changes in the psychological, physical and social domains are experienced by the adolescents that have led to aggression which is a common phenomenon occurring in this phase of life. Factors like poverty, exposure to media, violence and the environmental apathy provides such situations that can contribute to culture of violence.

Coping is an important construct in response of adolescents to the extensive stressors and adjustments they experience. It is very helpful for adolescents not only to have the understanding and support from peers and adults, but they are able to manage the stressor of everyday life by themselves. Schools are important locations for implementing intervention programs to prevent or reduce aggressive behavior with almost universal access to children. Keeping this in mind the study was conducted with the following objectives: To analyse the personal and socio-economic profile of adolescents. To identify the factors influencing adolescents' aggression.

\section{Materials and Methods}

The study was conducted in the schools of Hisar district of Haryana state. 250 adolescents each in the age group of 13-15 years from school of Hisar district was purposively selected for the present study. Self prepared questionnaire was used to delineate socio-personal variables.

Standardized Aggression scale developed by Mathur and Bhatnagar (2012) was used to study the nature of adolescent aggressive behavior. In aggression scale, statements were in two forms i.e. positive and negative. 30 statements were in positive form and 25 were in negative forms. Higher scores show higher aggression level and lower scores show lower aggression level. Frequencies, percentages, z test and regression were used to draw meaningful inferences.

\section{Results and Discussion}

\section{Personal profile of rural and urban adolescents of Haryana}

Adolescents' personal profile via frequency distribution has been depicted in Table1. Results portrayed that on an overall basis, 60.40 percent of adolescents were $14^{+}-15$ years of age while 39.60 percent were 13-14 years of age in Haryana. In total, 47.60 percent of the adolescents were female and more than half $(52.40 \%)$ were male in Haryana. Information regarding ordinal position of the respondents in Haryana indicated that 35.20 percent adolescents had first ordinal position among siblings, followed by second, third, fourth and above fourth born with 34.40 percent, 18.80 percent and 11.60 percent respectively. It was cleared from the data that in Haryana, 44.40 percent adolescents had two siblings, 29.60 percent had three siblings, 20.80 percent had more than four siblings and 5.20 percent had one sibling respectively.

\section{Socio-economic profile of rural and urban adolescents}

Presented in Table 2 are the results pertaining to socio-economic profile of adolescents on the basis of area of residence. Table clearly envisages that more than half of the adolescents belonged to nuclear families $(80.00 \%)$ and rest 20 percent of adolescents belonged to joint families indicating thereby that joint family system is declining in the study areas.

With regard to caste, most of the adolescents from rural area belonged to SC category $(43.20 \%)$ followed by 29.60 percent of adolescents who were in General category and only 27.20 percent were in BC category. However among urban area's adolescents' less than half belonged to General category 
(40.00\%), remaining were falling in the SC and BC category $(36.00 \%$ and $24.00 \%$, respectively). Out of total adolescents, 39.60 percent were from SC category, 38.80 percent were from General category and 25.60 percent were from BC category.

Figures pertaining to maternal educational background divulged that in rural area maximum proportion of mothers were illiterate $(74.40 \%)$. In urban area majority of the adolescents' mothers $(32.10 \%)$ were educated up to graduation. Out of total adolescents, 45.20 percent mothers were illiterate followed by matric $(20.80 \%)$, senior secondary $(18.40 \%)$ and graduation $(15.60 \%)$ indicating that there is low literacy rate among mothers.

The analysis of fathers' education revealed that more than one-third of fathers $(44.00 \%)$ from rural area were educated up to matriculation. From urban area 42.40 percent fathers were educated up to senior secondary level. On overall basis, most of the adolescents' fathers $(30.00 \%)$ were educated upto matriculation followed by senior secondary, graduation and illiterate $(29.60 \%$, $25.20 \%$ and $15.20 \%$, respectively).

A critical analysis of pattern of occupation helps to understand the economic position of the family, therefore, data relating to pattern of occupation of adolescents' mothers showed that maximum proportion of mothers from rural $(61.80 \%)$ and urban area $(40.80 \%)$ were housewives. It was found that out of the total sample, 51.20 percent mothers were housewives followed by laborer; service and business $(18.80 \%, 16.80 \%$ and $13.20 \%$, respectively).

Turning to paternal occupation, data revealed that majority of adolescents' fathers $(61.60 \%)$ from rural area were farmers while most of the adolescents' fathers of urban area
(33.60\%) were employed in government jobs which clearly shows that an edge of parents in respect of family income and better economic position of urban area than that of rural area. Further results revealed that majority of father (38.00\%) were engaged in farming followed by service $(25.60 \%)$. Almost equal numbers of adolescents' fathers were engaged in labor work followed by business with 18.80 percent.

Income is an important indicator of the standard of living, therefore, analysis of distribution of sample according to income becomes imperative and thus income wise distribution of families of adolescents' highlighted that majority of the families (73.60\%) residing in rural area of both the states had income below ₹ 10000 whereas families residing in urban area $(41.60 \%)$ had monthly income up to ₹ 10001- 20000. Overall results indicated that majority of the adolescents' families $(48.80 \%)$ had income below ₹ 10000 .

\section{Media exposure of adolescents}

Table 3 elucidates area wise exposure to mass media (both printed and non-printed). It was found that most of the adolescents $(68.00 \%)$ had medium access to mass media in rural area whereas in urban area $s$ majority of adolescents $(71.20 \%)$ had high exposure to mass media i.e. they had access of television, magazine, newspaper, internet and radio etc. Further data related to time spent in watching TV in both the residential area showed that majority of the adolescents $(63.20 \%$ and $70.40 \%$, respectively) were spending 1-2 hours in watching TV. It was found from the researches that children learned aggressive behaviour by watching and imitating the behavior of others. Further it was suggested by Aronson et al., 2005 that children who watches violence on television increases the probability of short-term aggression. 
On overall basis, it was found that most of the adolescents'(66.80\%) were spending 1-2 hours in watching TV followed by more than 2-3 hours (33.20\%). The figures for programmes watched on television exposed that in both the residential area maximum number of adolescents' liked to watch only entertainment programmes $(92.80 \%$ and $58.40 \%$, respectively). Further, overall data declared that more than one-fourth adolescents preferred to watch only entertainment programmes $(75.60 \%)$.

\section{Gender wise comparison of aggression among adolescents}

Details regarding gender wise comparison of selected sample are displayed in Table 4. Significant differences existed in physical $(\mathrm{z}=$ 4.72 and 2.67), verbal $(z=5.30$ and 2.34), relational $(\mathrm{z}=4.20$ and 4.56$)$ and overall aggression $(\mathrm{z}=5.48$ and 2.80) across gender. Mean scores highlighted that in rural area; physical aggression $(\bar{X}=48.75)$ was more in male adolescents while verbal $(\bar{X}=55.97)$ and relational aggression $(\overline{\mathrm{X}}=148.32)$ was high in female adolescents. Similarly in urban area, male adolescents had high physical $(\overline{\mathrm{X}}=$ 45.70) and verbal aggression $(\bar{X}=52.23)$ whilst relational aggression $(\bar{X}=149.53)$ was high in female adolescents. These findings get support from Faied (1996). Similar findings were reported by Jaffe et al., (2009) in his study which revealed that boys consistently perpetrated more physical aggression than girls. Lansford et al., (2012) also found that boys showed more physically aggressive behavior than girls. Overall aggression showed that mean score in rural area was more in females $(\bar{X}=211.07)$ whereas in urban area the mean score of males was higher $(\bar{X}=197.79)$. This result is supported by Onukwufor (2013) that prevalence of verbal aggression was higher among males than females. The result also corroborates
Atkin et al., (2002) who found that verbal aggression is widespread. The result is also in agreement with a study conducted in Spain, by Ramirez (1993) who found that boys justified verbal aggression more than girls. Similarly in Himachal Pradesh, physical and verbal aggression was more in boys and relational aggression was higher in girls in both rural and urban area (Shaffer, 2005). The findings of Akinlolu et al., (2011) suggest that male respondents were the main perpetrators of aggression in both urban and rural areas but more females in the rural areas perpetrated violence than their urban counterparts. Rivers and Smith (1994) research shows that boys have more direct physical aggression while girls have more indirect aggression. The study of Baldry (1998) indicated that bullying behaviors like threats, physical harm, rejection, and name-calling are more in boys, while girls are more involved in name-calling, teasing, rumors, rejection etc. Horn (2003) found that girls are more likely to say that it is morally wrong to exclude someone based on their crowd membership. However, this tendency for girls to engage in relational aggression more so than for boys might be influenced by different socialization of male and female children and different social expectations associated with gender roles.

Stepwise regression to predict aggression of adolescents from socio-personal variables

The results of stepwise regression analysis predicting aggression of adolescents are depicted in Table 5. The regression model revealed gender, family income, ordinal position, age, paternal education and maternal education as the significant predictors for aggression in adolescents. Gender in the Step I alone contributed to 21 percent of variance in aggression of adolescents. The model for the gender was significant, $F_{(1,248)}=56.81$, $\mathrm{p}<0.05$ (Model I). 
Next when family income was added, it accounted for 25 percent variance in the adolescent's aggression and the model was significant $\mathrm{F}_{(2,248)}=34.24, \mathrm{p}<0.05$ (Model II). Further, ordinal position in conjunction with gender and family income contributed to 27 percent variance and the analysis of variance of the hierarchical regression data produced F-ratio value significant at 0.05 level, $\mathrm{F}_{(3,248)}=25.99, \mathrm{p}<0.05$ (Model III).

In Step IV when paternal education was entered in the regression equation in addition to aggression, family income and ordinal position the model was found significant, $\mathrm{F}_{(4 \text {, }}$ $247)=23.61$, and accounted for 30 percent variance towards aggression of adolescents(Model IV). In the series, 31 percent variance in the adolescents' aggression was contributed by maternal education in conjunction with gender, family income, ordinal position and paternal education and the model was significant, $\mathrm{F}_{(5}$, 246) $=19.36, \mathrm{p}<0.05$ (Model V).

Demosthenous et al., (2002) indicated that socio-economic disadvantage was adversely associated with gender aggressiveness. Conforming the same Swaim et al., (2006) reported that most consistent set of predictors for aggression was gender, family actions against violence, peer violence, anger, academic performance, and alcohol use. Etim and Egodi, 2013; Kokko et al., 2014;Rahman et al., 2014; Wahdan et al., 2014 also reported similar findings.

Table.1 Personal profile of rural and urban adolescents of Haryana

\begin{tabular}{|c|c|c|c|c|c|}
\hline Sr. No. & Variable & $\begin{array}{c}\text { Rural } \\
(n=125)\end{array}$ & $\begin{array}{c}\text { Urban } \\
(n=125)\end{array}$ & $\begin{array}{c}\text { Total } \\
(n=250)\end{array}$ & $\begin{array}{c}\text { Total } \\
(n=250)\end{array}$ \\
\hline \multirow[t]{3}{*}{1.} & Age & & & & \\
\hline & 13-14 years & $51(40.80)$ & $48(38.40)$ & $99(39.60)$ & $102(40.80)$ \\
\hline & $14^{+}-15$ years & $74(59.20)$ & $77(61.60)$ & $151(60.40)$ & $148(59.20)$ \\
\hline \multirow[t]{3}{*}{2.} & \multicolumn{4}{|l|}{ Gender } & \\
\hline & Boys & $73(58.40)$ & $58(46.40)$ & $131(52.40)$ & $122(48.80)$ \\
\hline & Girls & $52(41.60)$ & $67(53.60)$ & $119(47.60)$ & $128(51.20)$ \\
\hline \multirow[t]{5}{*}{3.} & \multicolumn{4}{|l|}{ Ordinal position } & \\
\hline & First born & $42(33.60)$ & $46(36.80)$ & $88(35.20)$ & $63(25.20)$ \\
\hline & Second born & $32(25.60)$ & $54(43.20)$ & $86(34.40)$ & $103(41.20)$ \\
\hline & Third born & $30(24.00)$ & $17(13.60)$ & $47(18.80)$ & $55(22.00)$ \\
\hline & Fourth born and above & $21(16.80)$ & $8(6.40)$ & $29(11.60)$ & $29(11.60)$ \\
\hline \multirow[t]{5}{*}{4.} & \multicolumn{4}{|l|}{ Number of siblings } & \\
\hline & One & - & $13(10.40)$ & $13(5.20)$ & $9(3.60)$ \\
\hline & Two & $46(36.80)$ & $65(52.00)$ & $111(44.40)$ & $127(50.80)$ \\
\hline & Three & $40(32.00)$ & $34(27.20)$ & $74(29.60)$ & $78(31.20)$ \\
\hline & Four and more than four & 39 (31.20) & $16(12.80)$ & $52(20.80)$ & $36(14.40)$ \\
\hline
\end{tabular}

Note: Figures in parentheses indicate percentages 
Table.2 Socio-economic profile of rural and urban adolescents

\begin{tabular}{|c|c|c|c|c|c|}
\hline $\begin{array}{l}\text { Sr. } \\
\text { No. }\end{array}$ & Variable & $\begin{array}{c}\text { Rural } \\
(\mathbf{n}=125)\end{array}$ & $\begin{array}{c}\text { Urban } \\
(\mathbf{n}=\mathbf{1 2 5})\end{array}$ & $\begin{array}{c}\text { Total } \\
(\mathbf{n}=\mathbf{2 5 0})\end{array}$ & $\begin{array}{c}\text { Total } \\
(n=250)\end{array}$ \\
\hline \multirow[t]{3}{*}{1.} & \multicolumn{5}{|c|}{ Type of Family } \\
\hline & Nuclear & $80(64.00)$ & $120(96.00)$ & $200(80.00)$ & $223(89.20)$ \\
\hline & Joint & $45(36.00)$ & $\begin{array}{c}5 \\
(4.00)\end{array}$ & $\begin{array}{c}50 \\
(20.00)\end{array}$ & $27(10.80)$ \\
\hline \multirow[t]{5}{*}{2.} & \multicolumn{5}{|c|}{ Caste } \\
\hline & SC category & $54(43.20)$ & $45(36.00)$ & $\begin{array}{c}99 \\
(39.60)\end{array}$ & $82 \quad(32.80)$ \\
\hline & ST category & - & - & - & $23 \quad(9.20)$ \\
\hline & $\mathrm{BC}$ category & $34(27.20)$ & $30(24.00)$ & $\begin{array}{c}64 \\
(25.60)\end{array}$ & $30 \quad(12.00)$ \\
\hline & General category & $37(29.60)$ & $50(40.00)$ & $\begin{array}{c}87 \\
(34.80)\end{array}$ & $115(46.00)$ \\
\hline \multirow[t]{5}{*}{3.} & \multicolumn{5}{|c|}{ Maternal education } \\
\hline & Illiterate & $93(74.40)$ & $20(16.00)$ & $113(45.20)$ & 104 (41.60) \\
\hline & Upto Matric & $22(17.60)$ & $30(24.00)$ & $\begin{array}{c}52 \\
(20.80)\end{array}$ & $62(24.80)$ \\
\hline & Matric $^{+}$to Senior Sec. & $\begin{array}{c}10 \\
(8.00)\end{array}$ & $36(28.80)$ & $\begin{array}{c}46 \\
(18.40)\end{array}$ & $54(21.60)$ \\
\hline & Senior Sec. ${ }^{+}$to Graduation & - & $39(31.20)$ & $\begin{array}{c}39 \\
(15.60)\end{array}$ & $30(12.00)$ \\
\hline \multirow[t]{5}{*}{4.} & \multicolumn{5}{|c|}{ Paternal Education } \\
\hline & Illiterate & $34(27.20)$ & $\begin{array}{c}4 \\
(3.20)\end{array}$ & $\begin{array}{c}38 \\
(15.20)\end{array}$ & $34(13.60)$ \\
\hline & Upto Matric & $55(44.00)$ & $20(16.00)$ & $\begin{array}{c}75 \\
(30.00)\end{array}$ & 65 (26.00) \\
\hline & Matric $^{+}$to Senior Sec. & $21(16.80)$ & $53(42.40)$ & $\begin{array}{c}74 \\
(29.60)\end{array}$ & 77 (30.80) \\
\hline & Senior Sec. ${ }^{+}$to Graduation & $15(12.00)$ & $48(38.40)$ & $\begin{array}{c}63 \\
(25.20)\end{array}$ & $74(29.60)$ \\
\hline \multirow[t]{5}{*}{5.} & \multicolumn{5}{|c|}{ Maternal Occupation } \\
\hline & Housewife & 77 (61.60) & $51(40.80)$ & $128(51.20)$ & $113(45.20)$ \\
\hline & Labourer & $23(18.40)$ & $24(19.20)$ & $\begin{array}{c}47 \\
(18.80)\end{array}$ & $46(18.40)$ \\
\hline & Business & $\begin{array}{c}11 \\
(8.80)\end{array}$ & $22(17.60)$ & $\begin{array}{c}33 \\
(13.20)\end{array}$ & $32(12.80)$ \\
\hline & Service & $14(11.20)$ & $28(22.40)$ & $\begin{array}{c}42 \\
(16.80)\end{array}$ & $59(23.60)$ \\
\hline \multirow[t]{5}{*}{6.} & \multicolumn{5}{|c|}{ Paternal Occupation } \\
\hline & Farmer & $77(61.60)$ & $18(14.40)$ & $\begin{array}{c}95 \\
(38.00)\end{array}$ & $\begin{array}{c}94 \\
(37.60)\end{array}$ \\
\hline & Labourer & $16(12.80)$ & $31(24.80)$ & $\begin{array}{c}47 \\
(18.80)\end{array}$ & $\begin{array}{c}44 \\
(17.60)\end{array}$ \\
\hline & Business & $\begin{array}{c}10 \\
(8.00)\end{array}$ & $34(27.20)$ & $\begin{array}{c}44 \\
(17.60)\end{array}$ & $\begin{array}{c}40 \\
(16.00)\end{array}$ \\
\hline & Service & $22(17.60)$ & $42(33.60)$ & $\begin{array}{c}64 \\
(25.60) \\
\end{array}$ & $\begin{array}{c}72 \\
(28.80)\end{array}$ \\
\hline \multirow[t]{4}{*}{7.} & \multicolumn{4}{|c|}{ Income } & \\
\hline & $<₹ 10000$ & $92(73.60)$ & $30(24.00)$ & $122(48.80)$ & $104(41.60)$ \\
\hline & ₹10001- 20000 & $24(19.20)$ & $52(41.60)$ & $\begin{array}{c}76 \\
(30.40)\end{array}$ & $\begin{array}{c}90 \\
(36.00)\end{array}$ \\
\hline & > ₹20000 & $\begin{array}{c}9 \\
(7.20)\end{array}$ & $43(34.40)$ & $\begin{array}{c}52 \\
(20.80)\end{array}$ & $\begin{array}{c}56 \\
(22.40)\end{array}$ \\
\hline
\end{tabular}

Note: Figures in parentheses indicate percentages 
Table.3 Exposure of adolescents to mass media

\begin{tabular}{|c|c|c|c|c|}
\hline Sr. No. & Variable & $\begin{array}{c}\text { Rural } \\
(n=125)\end{array}$ & $\begin{array}{c}\text { Urban } \\
(n=125)\end{array}$ & $\begin{array}{c}\text { Total } \\
(n=250)\end{array}$ \\
\hline \multirow[t]{4}{*}{1.} & \multicolumn{4}{|l|}{ Media exposure } \\
\hline & Low & $7(5.60)$ & - & $7(2.80)$ \\
\hline & Medium & $85(68.00)$ & $36(28.80)$ & $121(48.40)$ \\
\hline & High & $33(26.40)$ & $89(71.20)$ & $122(48.80)$ \\
\hline \multirow[t]{3}{*}{2.} & \multicolumn{4}{|l|}{ Duration } \\
\hline & $1-2$ hours & $79(63.20)$ & $88(70.40)$ & $167(66.80)$ \\
\hline & More than 2-3 hours & $46(36.80)$ & $37(29.60)$ & $83(33.20)$ \\
\hline \multirow[t]{3}{*}{3.} & \multicolumn{4}{|l|}{ Programs preferred to watch } \\
\hline & Entertainment & $116(92.80)$ & $73(58.40)$ & $189(75.60)$ \\
\hline & Entertainment and Informative & $9(7.20)$ & $52(41.60)$ & $61(24.40)$ \\
\hline
\end{tabular}

Note: Figures in parentheses indicate percentages

Table.4 Gender wise comparison of aggression among adolescents

\begin{tabular}{|c|c|c|c|c|}
\hline \multirow{2}{*}{$\begin{array}{l}\text { Sr. } \\
\text { No. }\end{array}$} & \multirow[t]{2}{*}{ Aggression } & \multicolumn{3}{|c|}{ Rural (125) } \\
\hline & & $\begin{array}{c}\text { Male } \\
(\text { Mean } \pm \text { S.D. }) \\
(n=73)\end{array}$ & $\begin{array}{c}\text { Female } \\
(M e a n \pm \text { S.D. }) \\
(\mathbf{n}=52)\end{array}$ & $\begin{array}{c}\text { Z- } \\
\text { values }\end{array}$ \\
\hline 1. & Physical & $48.75 \pm 7.56$ & $42.25 \pm 7.62$ & $4.72 *$ \\
\hline 2. & Verbal & $52.01 \pm 5.24$ & $55.97 \pm 2.91$ & $5.30 *$ \\
\hline 3. & Relational & $136.31 \pm 10.56$ & $148.32 \pm 6.77$ & $4.20 *$ \\
\hline \multirow[t]{3}{*}{4.} & Overall & $181.27 \pm 31.53$ & $211.07 \pm 28.97$ & $5.48 *$ \\
\hline & & \multicolumn{3}{|c|}{ Urban (125) } \\
\hline & Aggression & $\begin{array}{c}\text { Male } \\
(\text { Mean } \pm \text { S.D. }) \\
(n=58)\end{array}$ & $\begin{array}{c}\text { Female } \\
(\text { Mean } \pm \text { S.D. }) \\
(n=67)\end{array}$ & $\begin{array}{c}\text { Z- } \\
\text { values }\end{array}$ \\
\hline 1. & Physical & $45.70 \pm 8.64$ & $41.52 \pm 8.79$ & $2.67 *$ \\
\hline 2. & Verbal & $52.23 \pm 5.34$ & $50.92 \pm 6.34$ & $2.34 *$ \\
\hline 3. & Relational & $136.02 \pm 10.96$ & $149.53 \pm 8.00$ & $4.56^{*}$ \\
\hline 4. & Overall & $197.79 \pm 44.99$ & $181.96 \pm 26.60$ & $2.80 *$ \\
\hline
\end{tabular}

* Significant at $5 \%$ level of significance 
Table.5 Stepwise regression to predict aggression from socio-personal variables

\begin{tabular}{|c|c|c|c|c|c|c|}
\hline \multirow{2}{*}{$\begin{array}{l}\text { Sr. } \\
\text { No. }\end{array}$} & Model & \multirow{2}{*}{$\begin{array}{c}\text { Standardized } \\
\text { coefficient } \\
(\boldsymbol{\beta})\end{array}$} & \multirow{2}{*}{$\begin{array}{c}\text { Standard } \\
\text { error }\end{array}$} & \multirow{2}{*}{$\begin{array}{c}\mathbf{t} \\
\text { value }\end{array}$} & \multirow{2}{*}{$\begin{array}{l}\text { Adjusted } \\
\mathbf{R}^{2}\end{array}$} & \multirow[t]{2}{*}{ F value } \\
\hline & Socio-personal variables & & & & & \\
\hline 1 & Step I Gender & 0.29 & 1.26 & $4.86^{*}$ & 0.21 & 56.81 \\
\hline 2 & $\begin{array}{r}\text { Gender } \\
\text { Family Income }\end{array}$ & $\begin{array}{r}0.26 \\
-0.17\end{array}$ & $\begin{array}{l}0.96 \\
1.10\end{array}$ & $\begin{array}{l}4.36^{*} \\
-2.86^{*}\end{array}$ & 0.25 & 34.24 \\
\hline 3 & $\begin{array}{r}\text { Gender } \\
\text { Family Income } \\
\text { Ordinal Position }\end{array}$ & $\begin{array}{r}0.24 \\
-0.17 \\
0.15\end{array}$ & $\begin{array}{l}0.95 \\
1.10 \\
1.81\end{array}$ & $\begin{array}{l}4.01^{*} \\
-2.83^{*} \\
2.63^{*}\end{array}$ & 0.27 & 25.99 \\
\hline 4. & $\begin{array}{rr}\text { Step IV } & \text { Gender } \\
\text { Family Income } \\
\text { Ordinal Position } \\
\text { Paternal Education }\end{array}$ & $\begin{array}{c}0.21 \\
-0.19 \\
0.18 \\
-0.14\end{array}$ & $\begin{array}{l}0.95 \\
1.10 \\
1.84 \\
1.25\end{array}$ & $\begin{array}{c}3.44^{*} \\
-3.18^{*} \\
3.10^{*} \\
-2.31 *\end{array}$ & 0.30 & 23.61 \\
\hline 5. & $\begin{array}{rr}\text { Step V } & \text { Gender } \\
\text { Family Income } \\
\text { Ordinal Position } \\
\text { Paternal Education } \\
\text { Maternal Education }\end{array}$ & $\begin{array}{r}0.22 \\
-0.10 \\
0.17 \\
-0.23 \\
-0.18\end{array}$ & $\begin{array}{l}0.94 \\
1.11 \\
1.83 \\
1.24 \\
0.76\end{array}$ & $\begin{array}{l}3.59 * \\
-3.22 * \\
2.94 * \\
-3.05^{*} \\
-1.98^{*}\end{array}$ & 0.31 & 19.36 \\
\hline
\end{tabular}

* Significant at 5\% level of significance

It can be concluded that aggression was more in females of rural area whereas in urban area reverse trend was found. Gender, family income, ordinal position, paternal education and maternal education were the significant predictors of the aggression in adolescents. This study provides with the evidence that family environment and socio-economic variables play a part in structuring the aggressive behaviour within adolescents. Poor family and socio economic variables can lead to behavioural problems among adolescents with consequences in aggressive behaviour. The findings of the results can help parents to figure out how family environment affects aggression. Aggression and emotional stress that develops in the earliest years of life is clearly linked to delinquent and criminal behaviour and other emotional problems in later life. Preventative interventions during the early years of life for effected or at risk families and adolescents will certainly reduce the prevalence and the seriousness of such behaviour problems.

\section{References}

Akinlolu O., Bridget O., Olusegun A., Folake O.O., Olujide O.A., Olorunfem O. and Olalekan A. 2011. Gender differences in students-staff violence in urban and rural secondary schools of Osun state, South Western Nigeria. Journal of Community Medicine and Primary Health Care, 23:1-2.

Aronson E., Wilson D.T and Akert M.R. 2005. Social Psychology, ( $5^{\text {th }}$ Edition $)$. Pearson Education, Inc.

Atkin C., Smith S.W., Roberto A.J., Fedriuk T. and Wagner T. 2002. Correlates of verbally aggressive communication in adolescents. Journal of Applied Communication Research, 30:251-268.

Baldry AC. 1998. Bullying among Italian middle school students. Sch Psychol Int, 19:361374.

Demosthenous H.T., Bouhours T. and 
Demosthenous C.M. 2002. Socio-economic status and youth aggression in Australia. Youth Studies Australia, 21: 11-15.

Etim E.T. and Egodi A.U. 2013. Family socioeconomic status and delinquency among Senior Secondary School students in Calabar south, cross river state, Nigeria. American International Journal of Contemporary Research, 3: 83-88.

Faied H.A. 1996. Dimensions of aggressive behavior among university students. Proceeding of the 3rd International Conference of the Centre of Psychological Counsellling, AinShams University, Cairo, Egypt, Pp.135-182.

Horn S.S. 2003. Adolescents' reasoning about exclusion from social groups. Developmental Psychology, 39: 71-84.

Jaffe K.J., Foshee F.A., Ennett S.T. and Suchindran C. 2009. The development of aggression during adolescence: Sex differences in trajectories of physical and social aggression among youth in rural areas. Journal of Abnormal Child Psychology, 36: 1227-1236.

Kokko K., Simonton S., Dubow E., Lansford J.E., Olson S.L., Huesmann R.L., Boxer P., Pulkkine P. and Pettit L. 2014. Country, sex, and parent occupational status: Moderators of the continuity of aggression from childhood to adulthood. Aggressive Behavior, 10: 552-567Lansford J.E., Skinner A.T., Sorbring E., Giunta L., Deater-Deckard K., Dodge K.A., Malone P.S., Oburu P., Pastorelli C., Tapanya S., Tirado L.M., Zelli A., Al-Hassan S.M., Alampay L.P., Bacchini D., Bombi A.S.,
Bornstein M.H., Chang L. 2012. Boys' and Girls' Relational and Physical Aggression in Nine Countries. Aggressive Behavior, 38: 298-308.

Mathur G.P. and Bhatnagar R. 2012. Aggression scale. National Psychological Corporation: Agra.Onukwufor J.N. 2013. Physical and verbal aggression among adolescents Secondary School students in rivers state of Nigeria. British Journal of Education, 1: 62-73.

Rahman A., Bairagi A. and Dey B.A. 2014. The Effect of socio-economic status and gender on adolescent anger in Chittagong. Journal of Humanities and Social Sciences, 19: 6368.

Ramirez J. 1993. Acceptability of aggression in four Spanish regions and a comparison with other European Countries. Aggressive Behaviour, 19:185-197.

Rivers L., Smith P.K. 1994. Types of bullying behaviour and their correlates. Aggressive Behavior, 20:359-368.

Shaffer D.R. 2005. Social and Personality Development. ( ${ }^{\text {th }}$ Edition). Belmont, CA: Wadsworth.

Swaim R.C., Henry K.L. and Kelly K. 2006. Predictors of aggressive behaviors among rural middle school Youth. Journal of Primary Prevention, 27: 229-243.

Wahdan N., Nimr E.R., Kotb R. and Wahdan A. 2014. Risk of aggression and criminal behaviour among adolescents living in Alexandria Governorate, Egypt. Eastern Mediterranean Health Journal, 20: 265272.

\section{How to cite this article:}

Deepika Sharma and Sheela Sangwan. 2019. Regional Study on Behavioural Tendency in Adolescents: Assessment and Analysis of Personal and Socio-Economic Environment. Int.J.Curr.Microbiol.App.Sci. 8(08): 2262-2270. doi: https://doi.org/10.20546/ijcmas.2019.808.262 